\title{
イソクエン酸脱水素酵素の臨床的研究
}

\author{
順天堂大学医学部第一内科教窒（指導村上精次教授） \\ 兴用俊即

\section{CLINICAL STUDIES ON ISOCITRIC DEHYDROGENASE}

Toshiro Sakurada

The 1st Department of Internal Medicine,

Juntendo University School of Medicine

(Prof. : Seiji Murakami)

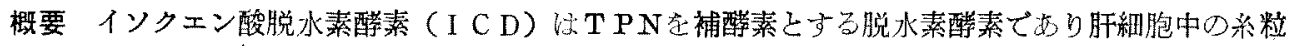
体に主として認められているが，著者心正常者执よび各種疾患々者血清中の本醭素活性值学測定した．

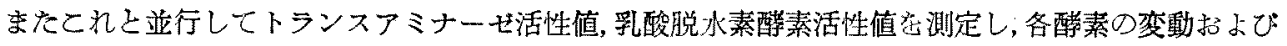

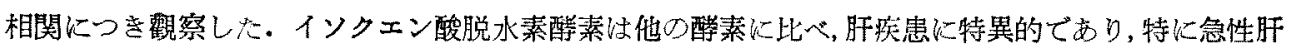

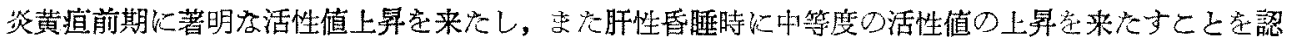
めた。慢性肝炎, 肝硬变では正常乃至は正常值を多少上通る活性値交不したが, 閉塞性黄㾝で一般 に上昇は認められず，二次的に肝細胞障害定来たした例には活性值上昇が認められた。その他の疾患 では I CD值は正常值を示した.メチルテストステロン招よびその誘尊体定投与した際に血中トラン スアミナーセ, 乳酸脱水素醉素, アルドターせ等の活性値の上昇するととが認められているが, 著者 は臨床並びに動物実験について検討し，イソクエン酸脱水素酰素活性值の上昇することを認めた。
\end{abstract}

\section{緒言}

旰はその機能上大きな予備力があり，かつ䫏著 な再生能を有する。ある種の旰疾患では形態学的 変化のあるものでも，ときに確立した旰機能検查 法によつて陰性の成績を得ることが往アある。ま た一方機能的障害の諗められるものでも, 盰の種 種の機能が一様に平行して侵されているとは限ら ない。このように䀒機能障害の程度の測定と，䀒 疾㭧診断との間にはいくつかの困難な点がある。

一般に慢性䀒疾患は比輘的緩徐に病变が進行する ものであるが，他方，畈組織は代償的に旺盛な网 生力を有する性筫上，結局旰機能効率上ではその 損失は全くないか，あつてもごく僅少に過ぎこ とがある。これに反してビールス性肝焱，中毒性

本諭女の要旨快第47回日本消化機病学会総会, 第58回 日本内科学会維全, 日本消化機病学会第3 回秋秄大会,

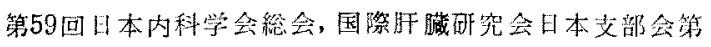
4 回総会にて笔起した。
肝资などにみられる広範な急性旰疾患では旰機能 を検查方れば，慢性旰疾、患時に比して恒常的に陽 性の成績が得られるものである。このような旰の 病態を動的に把握しようとの試み加ら，最近酵素 化学の進步とともに血清酵素化学的䇏断が有力な 補助診断として注目を㬇起されるに至つだ. 現在 すでにコリンエステラーゼ, アルカリフォスフォ ターゼ、トランスアミナーゼなどは, 旰疾患時の 病態を把握するために広く臨床的に応用されてい る現状である。

周知の如く, 旰は粕質中間代謝と密接な関係を

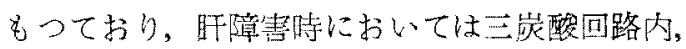
諸中間代謝産物の代謝暴常が認められることが諸 蒙により報告されておりわが教室の井手1は，高 アンモニア血症を己るなう䀒障害においては特に クエン酸および 珰められることを報告している。これら中間代

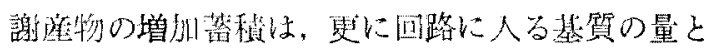


回路の反応速度との相対的な比率を考えなけれぼ ならないといわれている，1957年 Wolfson, William-Ashmann ${ }^{2)}$, ついで Mitchel13), Bowers ${ }^{4)}$ らは, 各種疾息々者について triphosphopyridine nucleotide (TPN) に特罣的な酵素の一つであ るイソクエン酸脱水絜酵素の血清中の活性值を測 定し, 䀒疾患では血清中に本酵素活性值の上昇を 諗め,こ㣗は䀒疾患に特異的であると述へている。 イソクエン酸脱水素酵素（以下ICDと略す）は 三炭酸回路の反庍速度を左右寸る因子の一つと 考えられ，イソクエン酸とTPNから $\mathrm{P}$ 方トグル タール酸と炭酸ガスおよび triphosphopyridine nucleotide hydrogen (T PNH) が生ずる反 店を触媒する酵装であるが，すでに Wolfson ら は各種疾患について血清本酵素活性值を測定し， 䀒疾患群においては特異的に上界することを認め ているが, 著者はI CDを中心とし、これと並行し て現在すでに臨床的に危用されている GPT・ GOT ・乳酸脱水素酵素（以下 $\mathrm{L} D H$ と略す）な ぞの血清中の酵素活性值を測定し，その変動につ いて観察した。

I ODに関して本邦においては高杉5), 石井6) らの報告もあるが, 本酵素の正常值について,いま だ確定的な報告に接しないので，著者はまずこの 正常值について検討し，更に各種聅㭧86例につい ての変動を観察すると>もに，そのうち20数例に ついては臨床経過にしたがい血清ＩＣＤの変㖶に ついて観察した。

Kochakian 以来, 男性ホルモンおよびその誘 導体には，性ホルモンとしての作用以外に蛋白同， 化作用があることが認められており，現在蛋白 同化ステロイド上して広く臨朱的に用いられてい る.しかしここの归化作用の本態は未だ詳細は解明

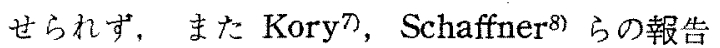
にタみられるごとく䀒々密接な関係を有すること がうかがわれ，条種トランスアミナ゙ーゼ， LDH， aldolaseなどの活性值上界がみとめられるので, 著者はこのステロイドのI CDへの影響を観察し た，更に著者は臨床的に得られた結果を精細に榆 討するため，実験的にイヌおよび家雭に数種の男 性ホルモン誘尊体を投与し, 血清および肝組織中 のI CDの㚆野を観祭した。

\section{実験方法および対象}

（1）試樂および湘定方法

A. 血清イソクエン酸脱水素酵素活性值（I

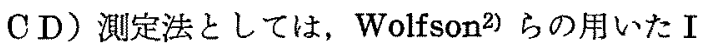
C D触媒により生じたT PNHを測定する方法が あるが，著者は Taylor9)の法に準じ，生じた $\alpha$ ケケグルタール酸を dinitrophenylhydrazine

（DN P H）により発色せしめて比色測定した。

\section{1) 試藥}

i ） $0.9 \%$ 食塩水

ii ） $0.01 \mathrm{M}$ 塩化マンガン液

iii） $0.1 \mathrm{M}$ 卜リ又緩衝液 ( $\mathrm{pH} 7.5$ )

iv) $5 \% \mathrm{EDTA}$ (ethylendiaminetetraacetate)

$\mathrm{v})$ イソクェン酸三 $\mathrm{Na}$ 塩 $(78 \mathrm{mg} / 0.9 \% \mathrm{NaCl}$ $3 \mathrm{ml}$ )

vi) $0.004 \mathrm{M}$ T PN (triphosphopyridine nucleotide)

vii) $0.001 \mathrm{M}$ DN PH(2,4-dinitrophenylhydrazine)

viii) $0.001 \mathrm{M} \alpha$-ケトグルタール 酸標準液

ix) $0.4 \mathrm{~N} \mathrm{NaOH}$

2) 測定方法

i ） 2 本の試験管におのおの血清 $0.5 \mathrm{cc}$ を採 り，0.001M塩化マンガン $0.4 \mathrm{cc}$ 加え，これに 更に $0.1 \mathrm{M}$ トリス緩衙液 $0.5 \mathrm{cc}$, イソクエン酸三 $\mathrm{Na}$ 塩 $0.2 \mathrm{cc}$ を加えて振盪混和し, 一方の試験管 は対照とした。

ii ）共に水温 $37^{\circ} \mathrm{C}$ に数分温浴.

iii）ついで検体には $0.004 \mathrm{M}$ TPN $0.4 \mathrm{Cc}$ 加え，一方対腊には $0.9 \%$ 食塭水 $0.4 \mathrm{cc}$ を加え, 更に水温 $37^{\circ} \mathrm{C}$ に60分温浴.

iv）温浴後おのおのの試験管に $0.001 \mathrm{M} \mathrm{DN}$ PH $1.0 \mathrm{cc} ， 5 \% \mathrm{EDTA} 0.2 \mathrm{cc}$ 加え振盪混和 し25分間室温放置.

v ）放置後おのおのの試験管に $0.4 \mathrm{~N} \mathrm{NaOH}$ 10ccを加之転倒湜和， 5 万至10分間内に Beckmann DU 光電比色棓を用い波長幅 $410 \mathrm{~m} \mu$, 又 リット幅0.46とし対照を透光率 $100 \%$ に合わせ比 色測定した

B. 血清乳酸脱水素酵素值（LDH）の測定は 
Hill ${ }^{10)}$ の方法に従つた。すなわ方 dihydrodiphosphopyridine nucleotide (DPNH) 添加し，DPNHの吸光度の減少により活性值を 測定した。

1) 試薬

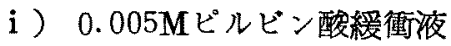

ii ） $0.1 \mathrm{M}$ 燐酸ソーダ經㣫液 $(\mathrm{pH} 7.2)$

iii) D P H 溶液 ( $1 \mathrm{mg} / \mathrm{ml}$ )

2) 測定与法

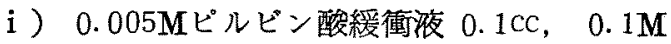
䗲酸ソーダ緩衝腋 2.5CC，DPNH $0.4 \mathrm{CC}$ ，これ らに更に 1：10稀䆁血清 $0.1 \mathrm{CC}$ を加える。

ii）他に稀釋血清の代りに0.1CC蒸留水を加え たものを对琞とした。

iii）検体㧈よび詨照を共に水温 $37^{\circ} \mathrm{C} 30$ 分温浴.

iv）Beckmann DU 光電比色計を用い波長幅 $340 \mathrm{~m} \mu$ ，スリット幅 0.187 とし, 対照を至適濃度 $0.500 に$ 合せ吸光度の減少により比色測定した。

C. 血清GPT値は Sigma-Frankel 法によ り測定した。

D. 血清GOT值は Sigma-Frankel 法によ り測定した。

(2) 実験対象

正常者は当大学附属病院職員および 健康若年 者，男20例，女16例，計36例をえらんだ。

患者は主として第一内科入院および外来患者中 の各種疾患，すなわち急性䀒炎15例，慢性旰炎 8 例, 䀒硬変 13 例, 閉塞性黄疸 6 例, 胆石症 3 例, 糖尿病 7 例，エリテマトーデス 2 例，ワイル病 2 例，心筋障害 4 例，鉛中毒 20 例，その他胃癌 1 例, 結腸癌 1 例, 胃潰㾤 2 例, ネフローゼ 2 例, 合計86例につき検查を行ない，またそのうち20数 例については，臨床経過を追つて血清各種酵素の 変動について検討した。

\section{実験成續}

I . (1) I C D正常値 (図 1)

正常例は36例で男20例の平均は $197 \pm 35.2$ 単 位（你険率 $5 \%$ ）であり，女16例の平均は $187 \pm$ 29. 3単位（他険率 5\%) で, 女は男に比しや>低

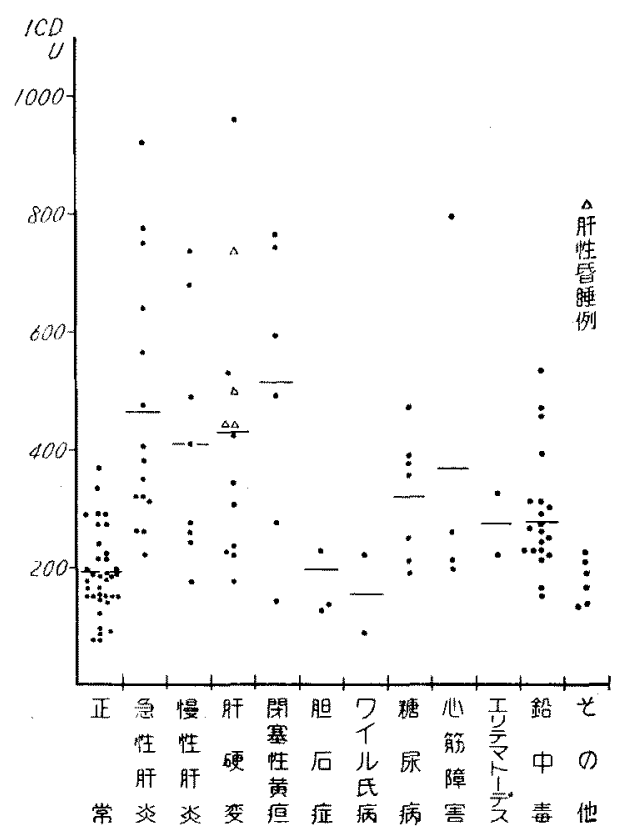

図1.各種疾患火和计るI C D 活性值

い值を示した。男女正常例36例の平均は $192 \pm 22$ .0単位であつた。

（2）諸種疾患（図 1)

1) 急性䀒炎（表 1)

急性盰炎15例の I C D值の平均は 464単位であ る. 症例 1,2,3 の黄疸前期 3 例の I C D值は扮の おの 750単位，640単位㧍よび 775単位といずれ も著しい高值を示し, 平均 722単位である. 泟例4, $5,6,7,8$ の黃㾝期 5 例は症例 5 を除き，いずれも I C D值は高值を示し，5例の平均は506単位で ある.ついで他の 7 例の回復期患者では, 症例 13 を 除き I C D值はほ ら゙正常乃至軽度上昇を示し，そ の平均は 323単位である。トランスアミナ一ゼ活 性と I C D活性値は，黄疸前期例で明らかな相関 をみ,かつGOTとGPTの比はGOT $/ \mathrm{GPT}<1$ である，他の䀒機能検査のうちチモール混濁反 応，セファリンコレステロール綿状反感は黄应前 期例では I C D活性值と有意の関係をみるが，他 の時期では必ずしも有意な相関を䖵めない。

2) 慢性肝炎（表 2)

慢性肝炎 8 例の I C D値の平均は 409単位であ 
表 1。急性䀒炎㮣者のI C D 諸肝機能成紸

\begin{tabular}{|c|c|c|c|c|c|c|c|c|c|c|c|c|c|c|c|}
\hline 症 & 性年令 & $\begin{array}{c}100 \\
U\end{array}$ & $\begin{array}{c}\text { GPT } \\
U\end{array}$ & $\begin{array}{c}\text { GOT } \\
U\end{array}$ & $\begin{array}{c}\angle D H \\
U\end{array}$ & $M G$ & $\begin{array}{c}B S P \\
45^{\prime} \\
\%\end{array} \mid$ & $\left|\begin{array}{c}T-p \\
9 / d t\end{array}\right|$ & $\left|\begin{array}{l}A / \\
g / d L\end{array}\right|$ & $\left|\begin{array}{l}G \prime \\
g^{\prime} \\
d t\end{array}\right|$ & $A / G$ & & & & $\mid \begin{array}{l}p_{n-1} \\
m i n-l\end{array}$ \\
\hline 7 & \begin{tabular}{|l|l|}
$\hat{\delta} 43$ \\
\end{tabular} & 750 & 94 & 20 & $=$ & 6 & 9 & 54 & 2.3 & 3.1 & 0.74 & 7.5 & H & - & 3.7 \\
\hline 2 & 524 & 640 & 137 & 72 & 155 & 15 & 5 & 6.8 & 3.3 & 3.5 & 0.94 & 4.4 & $+1+$ & - & 2.9 \\
\hline 3 & 542 & 775 & 250 & 71 & - & 10 & $=$ & - & - & - & $1-$ & 6.3 & $\mathrm{HH}$ & - & 8 \\
\hline 4 & 5146 & 382 & 92 & 41 & - & 28 & 12 & - & - & - & & 9.0 & $\mathrm{HI}$ & - & 4.0 \\
\hline 5 & \begin{tabular}{|l|l|}
139 \\
\end{tabular} & 260 & 95 & 115 & $\overline{-}$ & 30 & - & 6.7 & 3.7 & 3.0 & 1.23 & 0.4 & - & - & 2.2 \\
\hline 6 & \begin{tabular}{|l|ll}
0 & 62 \\
\end{tabular} & 565 & 220 & 125 & 110 & 54 & 45 & 6.9 & 3.8 & 3.1 & 1.22 & 1.3 & - & - & - \\
\hline 7 & \begin{tabular}{|l|l|}
9 & 28 \\
\end{tabular} & 920 & 243 & 405 & 130 & 170 & 64 & 82 & 4.0 & 4.2 & 0.95 & 6.4 & + & - & 3.3 \\
\hline 8 & \begin{tabular}{|l|ll}
9 & 60 \\
\end{tabular} & 405 & 17 & 18 & - & 233 & 10 & 70 & 3.5 & 3.5 & 1.00 & \begin{tabular}{|l|}
1.6 \\
\end{tabular} & - & - & - \\
\hline 9 & \begin{tabular}{|l|l|l|}
\multirow{8}{8}{} & 43 \\
\end{tabular} & 320 & 100 & 37 & - & 14 & 12 & 7.9 & 38 & 4.1 & 0.93 & 3.5 & - & - & 1.9 \\
\hline 10 & \begin{tabular}{|l|l|l|l|}
+19 \\
\end{tabular} & 350 & 31 & 18 & - & 10 & 19 & 8.2 & 4.3 & 3.9 & 1.10 & 1.3 & - & - & \\
\hline 11 & 926 & 3.20 & 78 & 50 & 40 & 10 & 13 & 6.6 & 2.1 & 4.5 & 0.47 & 6.0 & + & - & - \\
\hline 12 & \begin{tabular}{|l|l|l|}
1 & \\
\end{tabular} & $3 / 2$ & 11 & 9 & - & 9 & 5 & 7.7 & 4.0 & 3.7 & 108 & 1.8 & - & -1 & 1.7 \\
\hline 13 & \begin{tabular}{|l|l|l|}
$\hat{\delta}$ & \\
\end{tabular} & 475 & 71 & 102 & 180 & 7 & 14 & 6.7 & 3.7 & 3.0 & 1.23 & 6.2 & H & 二 & - \\
\hline 14 & $\begin{array}{l}937 \\
\end{array}$ & 260 & & 22 & 55 & 17 & 30 & 7.5 & 3.1 & 4.4 & 0.70 & 0.9 & \# & $R \& 4$ & 40 \\
\hline 15 & \begin{tabular}{|l|ll}
8 & 17 \\
\end{tabular} & 220 & 10 & 14 & 45 & 18 & 7 & 9.0 & 3.9 & \begin{tabular}{|l|}
5.1 \\
\end{tabular} & 0.76 & 9.2 & - & R41. & 4.4 \\
\hline & 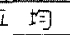 & 464 & 97 & & & & & & & & & & & & \\
\hline
\end{tabular}

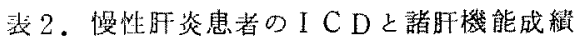

\begin{tabular}{|c|c|c|c|c|c|c|c|c|c|c|c|c|c|c|c|c|}
\hline 佂 & 性 & $\begin{array}{l}\text { 年 } \\
\text { 令 }\end{array}$ & $\begin{array}{c}100 \\
u \\
\end{array}$ & $\begin{array}{c}G P T \\
U\end{array}$ & $\begin{array}{c}\text { GoT } \\
0\end{array}$ & $\begin{array}{c}\angle D H \\
U\end{array}$ & $M G$ & $\begin{array}{r}B S P \\
45 \\
\%\end{array}$ & $\left.\mid \begin{array}{l}7-p \\
9 \neq 01\end{array}\right]$ & $\begin{array}{l}A l \\
g / d t \\
\end{array}$ & \begin{tabular}{|l|}
$G \prime$ \\
9 \\
$g$
\end{tabular} & $A / G$ & & & $\cos$ & $\begin{array}{ll}A \\
p_{n-1}-t\end{array}$ \\
\hline 1 & 占 4 & & 410 & 15 & 23 & - & 9 & 18 & 0.6 & 2.1 & 4.5 & 0,87 & 6.7 & $\mathrm{~m}$ & - & \\
\hline & $\hat{s}$ & 70 & 73 & 35 & 53 & - & & 5 & 68 & 3.0 & 3.8 & 0.78 & 4.1 & - & $=$ & \\
\hline & $\hat{b}$ & 24 & 245 & & & $=$ & 7 & 12 & $7 t$ & 3.0 & 4.1 & 0.73 & 6.0 & $H$ & $R_{311}$ & 4.1 \\
\hline 4 & $B$ & 36 & 275 & 53 & 3 & 50 & 7 & 25 & \begin{tabular}{|l|}
6.2 \\
\end{tabular} & 3.4 & 2.8 & 1.21 & 6.5 & + & $R ? t$ & 1.7 \\
\hline 5 & $q$ & 61 & 260 & 5 & 10 & 78 & 17 & 10 & 6.0 & 2.8 & 3.2 & 0.87 & 4.0 & H+ & RS & 24 \\
\hline 6 & 오 & 21 & 736 & 163 & 38 & & 25 & 40 & 7,5 & 2.6 & 4.9 & $0.5,3$ & 12.1 & $\mathrm{~m}+\mathrm{ll}$ & - & 9.4 \\
\hline 7 & $q$ & 45 & 490 & 64 & 51 & - & 6 & 10 & 122 & 30 & 4.2 & 0.71 & 6.9 & + & - & 110 \\
\hline 8 & 91. & 37 & 680 & 16 & 15 & - & 7 & 22 & 8.1 & 3.4 & 47 & 0.73 & 3.5 & $\mathrm{HH}$ & - & 1.7 \\
\hline 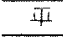 & 均 & & 409 & 41 & 55 & & & & & & & & & & & \\
\hline
\end{tabular}

り，全症例の半数に相当する 4 例（症例 $2,3,4,5$ ) のI CD值は, ほぶ正常範囲内である.トランスア ミナーゼ活性值と I C D活性値を比較すると， G P T活性上昇を示す症例では I C D 高活性を認 めるが，逆にＩＣD高活性症例では必ずしもGP T活性上昇が認められない，またGOTとGPT の比は GOT/GPT>1であり，I CD值は慢性 旰炎例では常にトランスアミナーゼ活性值と相関 関係にあるとはいい難い，また他の旰㙨能検査成 績と I C D活性值とを比較すると，A/G 比， チ モール混濁反応, セファリンコレステロール綿状 反応と I C D値との間には，特に有意の関係を認 めない

3）䀒硬変（表 3)

旰硬変13例の I C D値の平均は4 30 単位で, う
ち症例 $1,2,3,4$ の䀒性昏睡例の平均は 529篻位で あり，合睡例以外の 9 例の平均は386単位であ

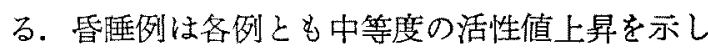
ているが, GP T, GOTは症例 4 を除き正常範囲 内にある。亦た各例とも黄疸指数，TTT， C C F拉よびアルカリフォスファターゼと I CD值の 間に正の相関を認め， A/G 比とは負の相関が認 められる。なお症例 2 は採血後 2 日目に死亡した 例である. 昏睡例以外の, 症例 5 より症例 1309 例 では, そのうち腹水, 脾腫, 腹壁静脈怒張, 食道静 脈瘤などをともなう 4 例(症例8，9，10，13)におい て，I C D值が正常範用内にあることが注目され る、G P T, GOTは 9 例ともすべてにおいて正常 值を示す，なお症例 9 は剖検により食道静脈瘤破 裂掞よび門脈血栓で死亡した症例で，また症例 
婊 3. 肝硬変症㭧者の I C D 墸旰機能成繢

\begin{tabular}{|c|c|c|c|c|c|c|c|c|c|c|c|c|c|c|c|c|c|c|}
\hline $\begin{array}{l}\text { 鈔 } \\
\text { 列 }\end{array}$ & 性 & & $\begin{array}{c}100 \\
U \\
\end{array}$ & $\begin{array}{c}\text { GPT } \\
U\end{array}$ & $\begin{array}{c}G 07 \\
U\end{array}$ & $\begin{array}{c}\angle D H \\
U\end{array}$ & $M \theta$ & $\begin{array}{l}B S P \\
45 \\
\%\end{array}$ & {$\left[\begin{array}{l}T-P \\
3 / d t\end{array}\right.$} & {$\left[\begin{array}{l}A / \\
g / d l\end{array}\right.$} & $\begin{array}{l}G l \\
g / d t\end{array}$ & $A / G$ & $T$ & $C c$ & & $\left\{\begin{array}{l}A l \\
P p_{n-1} \\
m M-1\end{array}\right.$ & $\begin{array}{c}N H_{3} \\
A^{\prime}\end{array}$ & $\begin{array}{l}3-N \\
B C\end{array}$ \\
\hline 1 & T) & 51 & 440 & 21 & 29 & - & 7 & $=$ & 0.2 & 3.0 & 3.2 & 0.94 & 6.0 & - & $=$ & 5.1 & $=$ & L \\
\hline 2 & i 1 & 34 & 497 & 24 & 35 & $=$ & 51 & $=$ & 7.0 & 1.6 & 5.4 & 0.29 & 6.6 & + & - & 4.6 & 1.32 & 125 \\
\hline 3 & $\delta$ & 41 & 443 & 13 & 60 & - & 25 & 33 & 62 & 29 & 3.3 & 0.87 & 5.4 & \pm & $f_{r(l)}$ & 5.9 & 141 & 1.57 \\
\hline 4 & o & 25 & 735 & 40 & 80 & 125 & 18 & 27 & 6.5 & 3.0 & 3.5 & 0.85 & 8.6 & H一⿻ & $A_{S t}$ & 4.0 & 117 & 1.11 \\
\hline 5. & 9 & 71 & 960 & 530 & 280 & 85 & 34 & 26 & 6.9 & 24 & 4.5 & 0.53 & 4.6 & 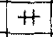 & $R_{S(1)}$ & 4.5 & $=$ & - \\
\hline 6 & b & 50 & 306 & 17 & 27 & - & $=$ & 18 & 6.0 & 22 & 3.8 & 0.58 & $A 1$ & \# & $\hat{f o b(1)}$ & - & $=$ & $=$ \\
\hline 7 & 8 & 54 & 427 & 5 & 20 & - & 14 & 8 & 5.9 & 23 & 3.6 & 0.63 & 11 & $=$ & $R_{2}$ & - & $=$ & - \\
\hline 8 & f & 43 & 220 & 6 & 20 & - & 7 & 15 & 8.4 & 1.9 & 4.5 & 0.42 & 60 & H & - & - & $L$ & $=$ \\
\hline 9 & 5 & 56 & 175 & 6 & 17 & 128 & 7 & 22 & 8.5 & 3.2 & 5.3 & 0.61 & $2 A$ & + & $R 7(1)$ & 60 & 1.42 & 131 \\
\hline 10 & f & 51 & 235 & 9 & 30 & 110 & 18 & 34 & 81 & 3.4 & 4.7 & 0.73 & 5.8 & H & $R x(f)$ & 22 & 1.15 & 0.91 \\
\hline 11 & 5 & & 227 & 55 & 46 & 75 & 5 & $\bar{p}$ & 70 & 3.5 & 3,5 & 1.00 & 51 & $t$ & $=$ & 7.5 & $=$ & - \\
\hline 12 & $\hat{b}$ & 47 & 580 & 45 & 35 & 50 & 8 & 21 & 79 & 2.6 & 5.3 & 0.49 & 7.0 & $=$ & RAil & 4.0 & 0.45 & 0.50 \\
\hline 131 & 81 & $54\}$ & 343 & 18 & 28 & 50 & 7 & - & 79 & 2.6 & 5.5 & 0.47 & 9.5 & \pm & $R \theta(2)$ & 29 & 0.67 & 1095 \\
\hline 互 & I均 & & 430 & 61 & 54 & & & & & & & & & & & & & \\
\hline
\end{tabular}

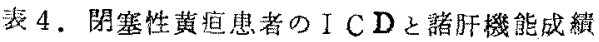

\begin{tabular}{|c|c|c|c|c|c|c|c|c|c|c|c|c|c|c|c|c|}
\hline $\begin{array}{l}\text { 症 } \\
\text { 列 } \\
\end{array}$ & 胜 & \begin{tabular}{|l} 
年 \\
命
\end{tabular} & $\begin{array}{c}100 \\
u\end{array}$ & $\begin{array}{c}G \rho T \\
U\end{array}$ & $\begin{array}{c}\text { GOT } \\
U\end{array}$ & $\begin{array}{c}\angle D H \\
U\end{array}$ & $M G$ & $\begin{array}{l}85 P \\
45 \\
\%\end{array}$ & $\frac{T-p}{g / d t}$ & $A /$ & $\begin{array}{l}G 1 \\
g / d\end{array}$ & $A / G$ & & & $C O R$ & 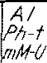 \\
\hline 1 & 19 & 52 & 595 & 37 & 48 & 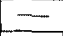 & 24 & 20 & 6.6 & 21 & 4.5 & 0.97 & 4.7 & + & - & 120 \\
\hline 2 & + & 31 & 491 & 86 & 59 & $=$ & 19 & 8 & 7.6 & 3.2 & 34 & 094 & 7,6 & $H$ & - & 6.9 \\
\hline 3 & 우 & 56 & 765 & 47 & 150 & $=$ & 120 & 41 & 58 & 21 & 3.7 & $0,5 ?$ & 5.6 & $+H$ & - & 9.8 \\
\hline 4 & $\hat{0}$ & 51 & 375 & 40 & 65 & - & 54 & 32 & 22 & 3.4 & 3.8 & 090 & 10.2 & +14 & Rr(z) & - \\
\hline 5 & 9 & 49 & 112 & 4 & 6 & - & 20 & 10 & 78 & 3.9 & 39 & 1.00 & 40 & - & $R_{311}$ & 4.0 \\
\hline$\delta$ & $q$ & 41 & 745 & 102 & 84 & - & 110 & 48 & 6.4 & 3.1 & 3.3 & 0.93 & 5.7 & + & - & 10.8 \\
\hline
\end{tabular}

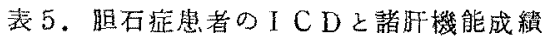

\begin{tabular}{|c|c|c|c|c|c|c|c|c|c|c|c|c|c|c|c|c|}
\hline $\begin{array}{l}\text { 症 } \\
\text { 例 } \\
\end{array}$ & 性 & & $\begin{array}{c}100 \\
0 \\
\end{array}$ & $\begin{array}{c}G P T \\
U\end{array}$ & $\begin{array}{c}G O T \\
U \\
\end{array}$ & $\begin{array}{c}\angle O H \\
U\end{array}$ & $M G$ & $\begin{array}{l}859 \\
45 \\
0 \%\end{array}$ & $\begin{array}{l}T-p \\
9 / d t\end{array}$ & {$\left[\begin{array}{l}A / \\
\theta / \sigma t\end{array}\right.$} & {$\left[\begin{array}{ll}G l \\
g / d l\end{array}\right.$} & $A / G$ & $7 I T$ & & & $\left\{\begin{array}{l}A 1 \\
P D-t \\
m M-U\end{array}\right.$ \\
\hline 1 & to & 52 & 127 & 7 & 6 & $=$ & 5 & 5 & 7.2 & 30 & 4.2 & 0.71 & 60 & - & - & 1.0 \\
\hline 2 & $\hat{\delta}$ & 48 & 135 & 3 & 3 & $=$ & 7 & 4 & 72 & 73 & 29 & 1.48 & 1.0 & - & - & 2.1 \\
\hline 3 & $\begin{array}{ll}9 \\
\end{array}$ & 64 & 325 & 14 & 20 & 70 & 6 & 7 & 6.9 & 35 & 34 & 102 & 10 & - & 1 & - \\
\hline
\end{tabular}

50 I C D活性值上昇は後起する男性ホルモン誘 莩体の影響によるものである。

4) 閉塞性黄疸（表 4)

閉塞性黄㾝 6 例の I CD嗔の平均は519単位で あり，最高 765笚位より最低 142単位にわたり広 く分布しており，急性旰炎の場合に類似してい る。症例 2 は試験開腹にて胆酸デスキネシーを 諗め，症例 3,6 は茄腫演による䀒外性閉塞性黄 疸であり，また症例 5 は $\mathrm{A} / \mathrm{G}$ 比, T T T, C C

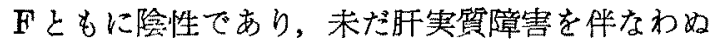
段階の肝外性閉塞性貲㾝である。艺の他の症例は， すへて旰実繁障書を伴なつた急性乃至は慢性の胆 道炎である。，Ｐ， GOTはIＣD活性值上昇 の諗められた症例のすへてに高活性を示した。

\section{5) 盟石症 (表 5)}

胆石症 3 例の I C D值の平均は196单位で正常 值を示し，GPT，GOTその他の諸䀒機能検查 成續にも暴常を認めなかつた。

6) エリデマトーデス（表 6)

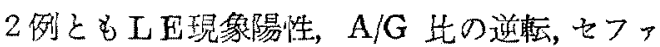
リン綿状反応陽性などの軗度の旰機能障害を言め るが，ルポイト䀒炎の所見はなく，I C D值は 任ぐ正常，GPT, GOT, LDH なども正常であ る.

\section{7) ワイル氏病（表 6 )}

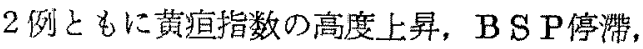
A/G 比の邀転をるが I CD， GPT， GOT， LDHはすへて正常值を示し，I CD更にはGP 
表 6.エリテマトーデス患者及びワイル氏病患者のI C D と賭肝機能成䋶

\begin{tabular}{|c|c|c|c|c|c|c|c|c|c|c|c|c|c|c|c|}
\hline & 性年 & $\begin{array}{c}100 \\
V\end{array}$ & $\begin{array}{c}G P T \\
U\end{array}$ & $\stackrel{G O T}{U}$ & $\begin{array}{c}\angle O H \\
U\end{array}$ & & $\left|\begin{array}{c}B S P \\
4 S \\
\%\end{array}\right|$ & $\begin{array}{l}T-\rho \\
g / d t\end{array}$ & $A / d / d$ & $\begin{array}{l}G / \\
g / d t\end{array} \mid$ & & 77 & & & $\begin{array}{l}A^{\prime} \\
P^{\prime}-A\end{array}$ \\
\hline & & & & & リ & & & & & & $\bar{x}$ & & & & \\
\hline & $9+33$ & 326 & 11 & 24 & 50 & 6 & 2 & 8.1 & 3.1 & 5.1 & 0.61 & 6.6 & $\mathrm{HI}$ & $R 7 t)$ & 22 \\
\hline 2 & \begin{tabular}{|l|l|l|}
58 \\
\end{tabular} & 220 & 18 & 27 & 140 & 9 & 8 & 6.3 & 3.0 & 3.31 & 0.90 & 3.8 & & & 21 \\
\hline & & & & & & & & 病 & & & & & & & \\
\hline & 919 & 220 & 18 & 39 & 140 & \begin{tabular}{|l|l|}
117 \\
\end{tabular} & 23 & 6.8 & 3.1 & \begin{tabular}{|l|}
3.7 \\
\end{tabular} & 0.83 & 4.0 & +4 & $R 3$ & 2.0 \\
\hline 2 & \begin{tabular}{|c|c|}
556 \\
\end{tabular} & 86 & 10 & 9 & 100 & 98 & 27 & 6.3 & 3.0 & 3.3 & & \begin{tabular}{|l|}
14 \\
\end{tabular} & + & $R_{3(t)}$ & $4 A$ \\
\hline
\end{tabular}

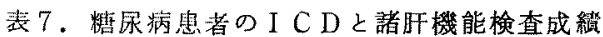

\begin{tabular}{|c|c|c|c|c|c|c|c|c|c|c|c|c|c|c|c|c|}
\hline 症 & 性年 & $\begin{array}{l}100 \\
U\end{array}$ & $\begin{array}{c}G P T \\
U\end{array}$ & $\begin{array}{c}\text { COT } \\
U\end{array}$ & $\begin{array}{c}\angle D H \\
U\end{array}$ & & $\begin{array}{l}B S A \\
45 \% \\
\%\end{array}$ & $r_{\rho}$ & $\begin{array}{l}A 1 \\
g / d t\end{array}$ & $\left|\begin{array}{ll}a l \\
g / d t\end{array}\right|$ & & & $\operatorname{CCF}$ & & $\begin{array}{c}A \\
P_{h-1} \\
m M-4\end{array}$ & $\begin{array}{l}\text { Fasting } \\
\text { Socood } \\
\text { Sugar }\end{array}$ \\
\hline 1 & \begin{tabular}{|l|l}
9 & 19 \\
\end{tabular} & 210 & - & $=$ & - & - & 70 & 7.0 & 2.6 & 4.4 & 0.59 & 111,6 & - & $R_{312}$ & - & 130 \\
\hline & \begin{tabular}{l|l|l}
9 & 67
\end{tabular} & 250 & 6 & 6 & - & 7 & - & 7.2 & 3.0 & 4.2 & 0.71 & 0.0 & + & & - & 98 \\
\hline & \begin{tabular}{|l|l|}
3 & 32 \\
\end{tabular} & 380 & 5 & 8 & - & - & 0 & 0.5 & 3.5 & 3.0 & $1 / 16$ & 0.9 & -1 & $\sqrt{R_{H 2}}$ & - & 115 \\
\hline 4 & \begin{tabular}{|l|l|}
9 & 43 \\
\end{tabular} & 190 & 3 & 5 & - & $\overline{-}$ & - & 2.1 & 3.2 & 3.9 & 0.82 & 40 & -1 & - & - & 110 \\
\hline 5 & \begin{tabular}{l|l}
9655 \\
\end{tabular} & 47 & 25 & 18 & $=$ & 9 & 8 & 68 & 3.0 & 38 & 0.78 & 5.1 & -1 & $=$ & - & 130 \\
\hline 8 & $\begin{array}{l}18.97 \\
\end{array}$ & 350 & 12 & 13 & - & 8 & 0 & 8.2 & 3.9 & 4.3 & 0.91 & 80 & -1 & $=$ & $=$ & 110 \\
\hline 7 & 18153 & 390 & 10 & 13 & - & 9 & 5 & 77 & 33 & 4.4 & & $4 !$ & -1 & $R_{3}$ & 1.3 & 123 \\
\hline
\end{tabular}

T，GOTなどと臨床検査成績との間には有意の 相関を認めない。

8）糖尿病（表 7 )

症例 1 は，若年性糖尿病㭧者でありインスリン にて加療中であるが，尿精 1 日量 $60 \mathrm{~g} ， \mathrm{~A} / \mathrm{G}$ 比 の逆転, チモール湜濁反応陽性であり,かつ総コレ ステロール量 $478 \mathrm{mg} / \mathrm{dl}$ で, 血清は乳糜状を呈し て㧍り，糖疗病としては重症であるが，IＤ＼cjkstart值は 正常である。症例 2 は，尿糖 1 日量 $30 \mathrm{~g}$ 前後，チ モール混濁反応およびセファリンコレステロール 綿状反応陽性, 綕コレステロール量 $290 \mathrm{mg} / \mathrm{dl}$ で あり，ICD值は正常である，その他の症例は治 療により栯病疮は軽快しており，いすれれも I C D 活性の軽度上昇を認めるが，糖尿病患者全 7 例の I CD值の平均は，321単位で糖尿病の病状，更 には栯永病による䀒障害と，I C D 活性值との間 には有意の関係を認め難い。

9）心筋障害症 (表 8)

表 8 。心筋障害恵者之各酸素活性値

\begin{tabular}{|c|c|c|c|c|c|c|}
\hline $\begin{array}{l}\text { 症 } \\
\text { 例 }\end{array}$ & 性 & \begin{tabular}{|}
$\mid$ 年 \\
令
\end{tabular} & $\begin{array}{c}100 \\
0\end{array}$ & $\begin{array}{c}G P T \\
U\end{array}$ & $\begin{array}{c}607 \\
U\end{array}$ & $\begin{array}{c}\angle O H \\
U\end{array}$ \\
\hline$/$ & 1 & 6.3 & $2 / 3$ & 4 & 9 & 100 \\
\hline 2 & 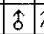 & 71 & 196 & 32 & 56 & 320 \\
\hline 3 & 8 & 56 & 795 & .504 & 416 & 370 \\
\hline 4 & 8 & 57 & 260 & 20 & 17 & 290 \\
\hline 可 & 均 & & 366 & 110 & 125 & \\
\hline
\end{tabular}

症例 1 は，心電図にてST降下を認めるが各醉 素活性值は正常, 症例 2 は, 硬塞発作後採血, G $\mathrm{PT}, \mathrm{GOT}, \mathrm{LDH}$ 各酵素活性值の上昇を示すがI $\mathrm{CD}$ は正常. 症例 3 は, 硬塞直後に採血し, 各酵 素活性值上昇, 検查後 3 病日にて死亡, 剖椧にて 心筋硬塞および軽度のうつ血旰を認めた症例で I C D值にも活性值上昇が認められた。症例 4 は, 心内膜下硬塞症にて死亡する 1 週間前に検查した もので，上DHの軽度上昇を認めるがその他の酵

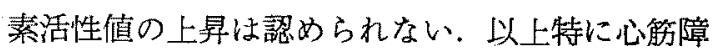
害と I C D活性值とは相関が認められなからた。

10）鉛中毒症

某工場に集団発生した鉛中毒患者で，年令は17 キより35才までの計20名につき I CD，LDHを 測定した結果，正常值の上限をこえる活性值を示 したものは測定対象の50\%に当る10例であつた。 10例中 3 例は 400単位をこえる高活性值を示した が,これと並行して行なつた諸旰機能検査とは有 意の関係なく，全症例を通じて特に䀒機能障害を 認めるものはなかつた。なおし DH值はいずれも 正常値を示した。

11）その他の疾患

腫额 2 例のI C D值はそれぞれ 190単位および 135単位, 胃溃演 2 例の I CD值は210単位およ 


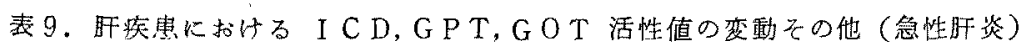

\begin{tabular}{|c|c|c|c|c|c|c|c|c|c|c|c|c|c|c|c|c|c|}
\hline 症 & l性 & $\begin{array}{l}\text { 年 } \\
\text { 令 }\end{array}$ & $\begin{array}{l}\text { 検党 } \\
\text { 特期 }\end{array}$ & $\begin{array}{c}1 C D \\
U\end{array}$ & $\begin{array}{c}G P T \\
U\end{array}$ & $\begin{array}{c}\text { GOr } \\
U\end{array}$ & $\begin{array}{c}\angle D H \\
U\end{array}$ & $M G$ & $\begin{array}{c}B S P \\
45 \\
\% \%\end{array}$ & $\left|\begin{array}{l}F P \\
\varphi / t\end{array}\right|$ & Al & $\begin{array}{l}\hat{G l} \\
g / d t\end{array}$ & $A / Q$ & & 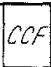 & & $\begin{array}{l}A \\
O h-t \\
m, 4\end{array}$ \\
\hline \multirow{2}{*}{1} & \multirow{2}{*}{$\hat{\delta} \mid 4$} & \multirow{2}{*}{4.3} & 荡 & 750 & 94 & 20 & - & 6 & 9 & 54 & 23 & 3.1 & 0.74 & 7.5 & H & $=$ & 3.7 \\
\hline & & & 㣪 & 520 & 53 & 50 & - & 31 & 15 & 54 & 2,3 & 31 & 074 & 600 & 卅 & - & 3.7 \\
\hline \multirow{2}{*}{2} & \multirow{2}{*}{\multicolumn{2}{|c|}{ s) 2}} & 前 & 640 & 137 & 72 & 155 & 15 & 5 & 68 & 3.3 & 3.5 & 0.94 & 44 & int & - & 29 \\
\hline & & & 㖟 & 260 & 81 & 40 & 100 & 39 & 18 & 68 & 3.3 & 3.5 & 0.94 & 6.2 & Ht & - & 3.0 \\
\hline \multirow[t]{2}{*}{3} & \multirow{2}{*}{\multicolumn{2}{|c|}{$\hat{\delta} 4$}} & 朤 & 775 & 250 & 71 & - & 10 & 23 & $=$ & $=$ & - & - & 0.3 & +11 & $=$ & 3.4 \\
\hline & & 42 & 後 & 230 & 4 & 11 & $=$ & $S$ & 5 & 811 & 3.9 & 42 & 0.93 & 40 & - & - & 3.0 \\
\hline \multirow[t]{2}{*}{4} & \multirow{2}{*}{$\hat{\delta}$} & & 前 & 382 & 92 & 41 & - & 28 & 12 & 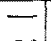 & - & - & - & 9.0 & H1 & 二 & 4.0 \\
\hline & & 40 & 後 & 360 & 9 & 12 & - & 21 & 15 & 7.2 & 3.6 & 3.6 & 100 & 0.0 & H & 一 & 40 \\
\hline
\end{tabular}

100

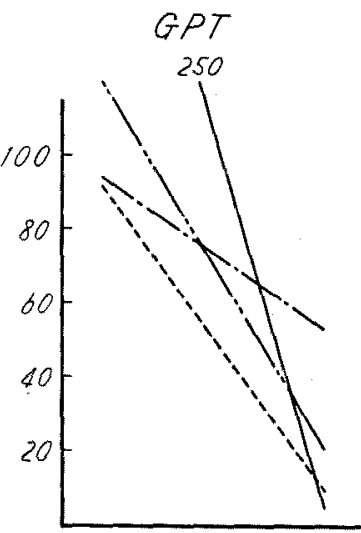

GOT

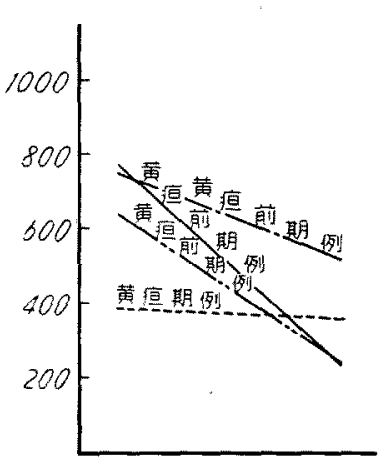

図2、䀒疾患に打ける

I C D, GOT, G P T 活性値の变動（急性旰炎）

び165単位,またネフローゼ2例のＩＯD值は 135 単位および 227 単位で,すへて正常範围内である。

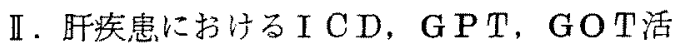
性値の変動

急性旰炎, 慢性肝炎, 旰硬変各 4 例について2 乃至 3週間々隔で I D , GPT，GOT各酵素 活性値の変動について観察した。急性肝炎 4 例中

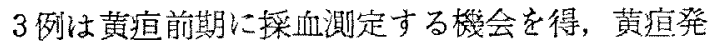
現後 2 乃至 3 週目に再度採血測定した結果， 3 例 とも各酵素活性值の著しい䯩值，ついで咸少する ことを覆察し得た，黄疸期 1 例む同様の傾向を示 したが，活性值減少率は特に黄疸前期より観察し

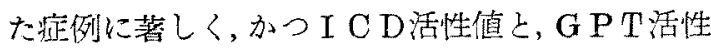
值変動との間には椙関が癹められる。䇥例 3 を除 き，他の症例に招いてはＩCD，GPT活性値の 正常化しな時期に扔いても，なお他の旰機能検查 の改善は認められなかつた（表 9, 図2). 慢性䀒
炎例では各酵素活性值の変動は一定の傾向がみら れない. 症例 4 の既往歷には急性旰炎があり、入院 封所機能検查では，BSP45分值40\%，A/G 圠 0.80，TTT， C C Fをに陽性，コバルト反応 右方推移がみられ，I CD 695単位と高活性值を 示しGPT67篻位，GOT46単位であつた。その 後つ肝機能桧查ではBS P45分值の変動, グロブ リンの增加がみられる以外に著しい変動のないの に反して，ICD，GPT，GOT値はいずれも 正常值の上限をこえて增減不同の変動を示してち り，従つて旰機能検查と相関が認められなかつ

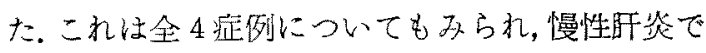
は I C D值は正常值䉓囲をこえて增淢をくり返し

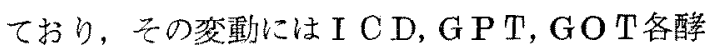

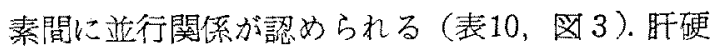
変例は，症例13を除きいずれも既睡㭙入院したも のを対象とし，症例 1 を除き高アンモニア血症を 示し感睡時および覚醒時，または覚醒後 2 乃至 3 


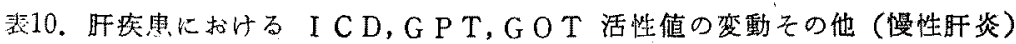

\begin{tabular}{|c|c|c|c|c|c|c|c|c|c|c|c|c|c|c|c|c|c|}
\hline 症 & 性 & & 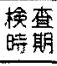 & $\begin{array}{c}100 \\
U\end{array}$ & $\begin{array}{c}G P T \\
U \\
\end{array}$ & $\begin{array}{c}\text { GOT } \\
0\end{array}$ & $\begin{array}{c}\angle O H \\
U\end{array}$ & $M G$ & \begin{tabular}{|c|}
$S S P$ \\
$45^{\prime}$ \\
$\%$
\end{tabular} & $\begin{array}{l}7-p \\
9 / d l\end{array}$ & $\begin{array}{l}A / \\
g / t \prime\end{array}$ & $\begin{array}{l}G i \\
g / d t\end{array}$ & $A / G$ & & $O$ & Con & $\begin{array}{l}A \\
P h-t \\
m M-U\end{array}$ \\
\hline \multirow{2}{*}{7} & \multirow[b]{2}{*}{0} & \multirow[b]{2}{*}{4} & 前 & 245 & 3 & 7 & - & 7 & 12 & 7.1 & 30 & 4.1 & 0.73 & 6.0 & H & $\mathrm{K} 36$ & 4.1 \\
\hline & & & 後 & 510 & 10 & 21 & - & 9 & 10 & 7.3 & 3.0 & 43 & 0.69 & 6.0 & + & $R 3 t$ & 4.1 \\
\hline \multirow{2}{*}{2} & \multirow{2}{*}{ 우 } & 2 & 前 & 736 & 103 & 238 & $=$ & 25 & 40 & 7.5 & 26 & 4.9 & 0.53 & 12.1 & $\mathrm{HH}$ & - & 9.4 \\
\hline & & & 㖟 & 920 & 555 & 350 & 二 & 19 & $=$ & 7.5 & 26 & 4.9 & 0.53 & 9,4 & $1+1+t$ & - & \\
\hline \multirow{2}{*}{3} & \multirow[t]{2}{*}{ 우 } & & 萠 & 680 & 16 & 15 & - & 7 & 22 & 81 & 3.4 & 4.7 & 0.73 & 3.5 & H & - & 1.7 \\
\hline & & 8 & 後 & 610 & 14 & 18 & - & 7 & 19 & - & 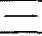 & 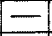 & - & - & $=$ & - & $=$ \\
\hline \multirow{3}{*}{4} & \multirow{3}{*}{9} & & 前 & 695 & 67 & 46 & 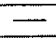 & 5 & 40 & 7.2 & 3.2 & 40 & 0.80 & 9.8 & III & 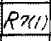 & 1.5 \\
\hline & & 45 & $\Phi$ & 490 & 64 & 51 & - & 6 & 10 & 72 & 3.0 & 42 & 0.71 & 6.9 & $t$ & $=$ & 1.0 \\
\hline & & & 後 & 855 & 97 & 93 & - & 7 & 15 & 6.6 & 2.1 & 4.5 & 0.47 & 40 & + & $P(t$, & 2.0 \\
\hline
\end{tabular}

$1 C D$

GPT

GOT
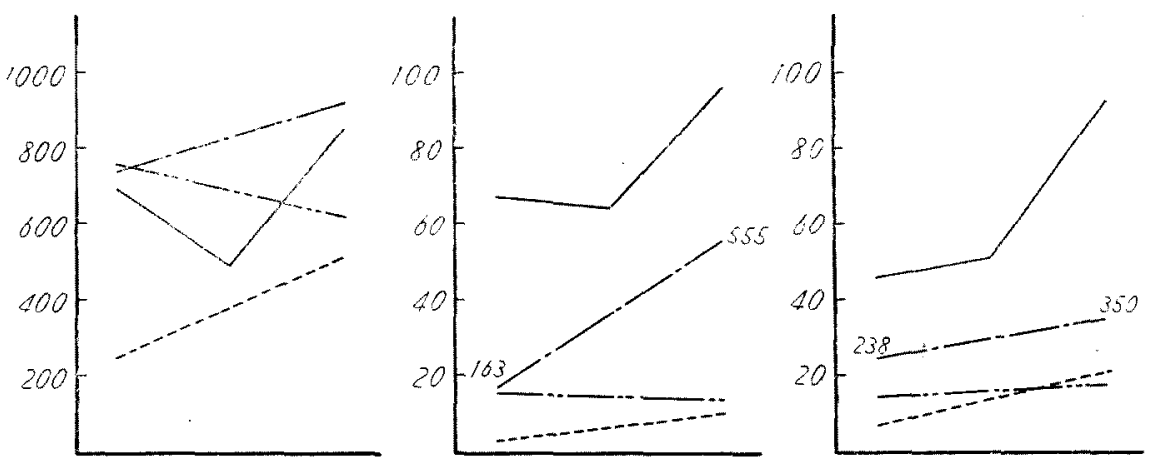

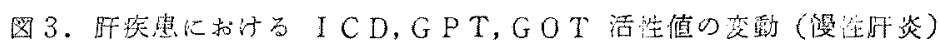

日目の2 回に採血を行なつた。症例13は，採血立日 に昏睡状態となり，皆睡前後 4 日にわたり各酵素 活性値の変趿を観察したものであるＩＩD少よ びGOTは皆睡时高健を示し，觉醄後日数の経過 とともに著しい減少を示したがGPT值ははぶ不 変であつた。な打症例数が少ないため高アンモニ ア血症と I C D活性値上昇との相関を知ることは できなかつた（表11，図4）。

小括. 急性䀒众より慢性䀒炎, 䀒硬変八の段 階に㧍ける I C D活性值の変動を一瞥すると，急 性旰炎では黄疸前期以著明な高活性を示し，黄疸 消退以斯に正常值の上限附近まで減少を示すが， 慢性畈炎に移行した症例に扔いては，正常ある い注罢常活性值を示しながら变動をくり还し，更 に䀒硬变に移行しても同様の变動をくり返し，旰 性管睡に陷ると 1 乃至 2 日掘孔て活性值上昇を示 し，ついで覚醒後次第に正常値に復帰する，従つ
て I CDの蕃明な高值のみられるのは急性旰炎前 半期と肝性昏腄時と考えられる（图５）、な括これ らの症洌中において，急性旰炎ではＩＣD高值の ものではGPT高值が䜑められた（図 6)。

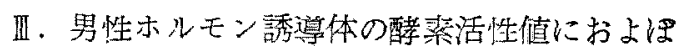
寸影響

1950年 Werner ${ }^{11)}$, 1952年 Almaden ${ }^{12)}$ らは

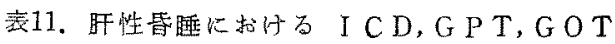
活性值の变動

\begin{tabular}{|c|c|c|c|c|c|c|c|}
\hline $\begin{array}{l}\text { 症 } \\
\text { 峢 }\end{array}$ & 性 & & 検 变城期 & $\begin{array}{c}100 \\
u\end{array}$ & $\begin{array}{c}G P T \\
U\end{array}$ & $\begin{array}{c}G O T \\
U\end{array}$ & $\begin{array}{l}\angle D H \\
U\end{array}$ \\
\hline & \multirow{2}{*}{$\hat{\delta}$} & & 皆隀 & 440 & 21 & 29 & $=$ \\
\hline & & & 賞醒 & 342 & 23 & 17 & $=$ \\
\hline \multirow{2}{*}{3} & \multirow{2}{*}{$\hat{\delta}$} & 4 & 笪睡 & 243 & 13 & 60 & $=$ \\
\hline & & 7 & 堂酲 & 410 & 5 & 12 & $=$ \\
\hline \multirow{2}{*}{4} & \multirow[t]{2}{*}{ t } & & 昏琶障 & 735 & 40 & 80 & 125 \\
\hline & & & 賞 醙 & 320 & 35 & 23 & 130 \\
\hline \multirow{4}{*}{13} & & & 乒䧉前 & 843 & 118 & 28 & 50 \\
\hline & & & 琶堲 & 390 & 12 & 23 & 70 \\
\hline & & & 昏皆睡 & 593 & 8 & 38 & 100 \\
\hline & & & 鲎 酲 & 380 & 28 & 28 & 80 \\
\hline
\end{tabular}


$1 C D$

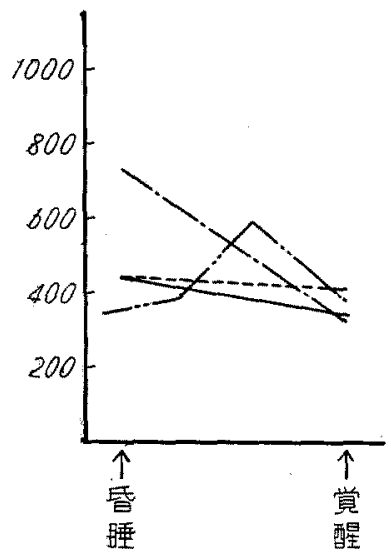

GPT

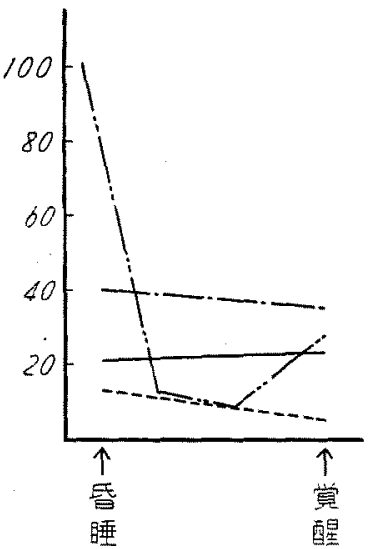

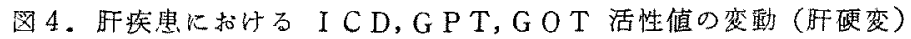

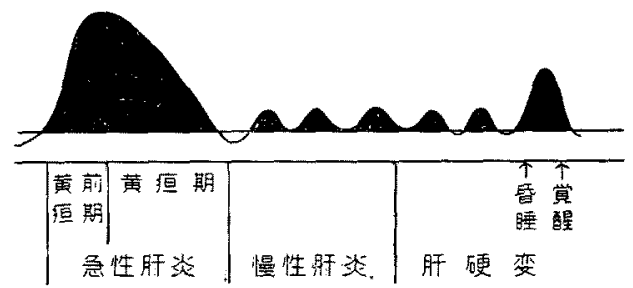

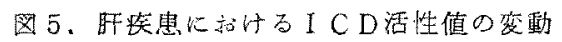
methyltestosterone propionate による治療中 に発名した黄疾について報告を行ないまた 年 Korybは蛋白同化ホルモンによる治漈中にB

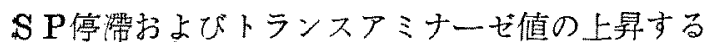
ここを都告しており，本邦においても堂野前13),

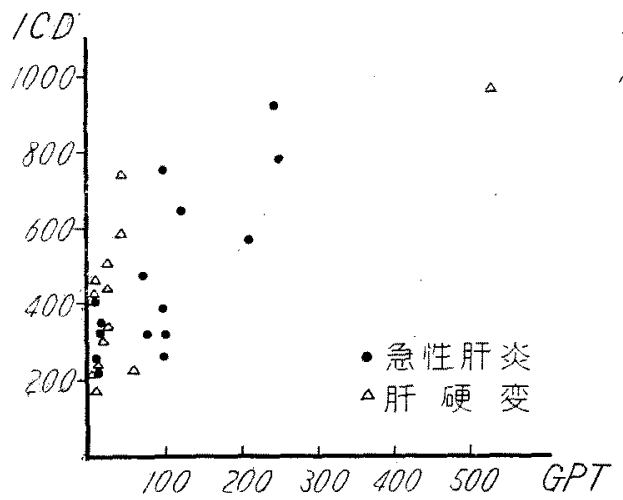

図6.肝疾患に指ける I C D と G P T
勝本14ららの報告方むる。このように男性ホルモン

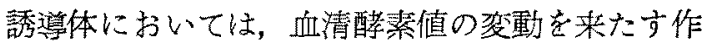
丹があることが報告されているが，その本態は未 だ解明されていないので，著者は肝細胞障害に密 接子関係を有するICDについて，男性ホルモン

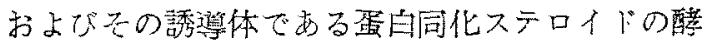

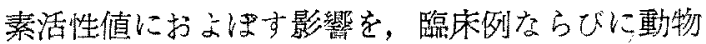
实験を行なつて検討し，考察を加えた。

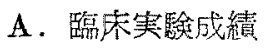

(1) methyltestosterone propionate (MT) 投与例 (圈 7 )

MT 10mg万至30mg 正常例，畈疾盘例儿投与

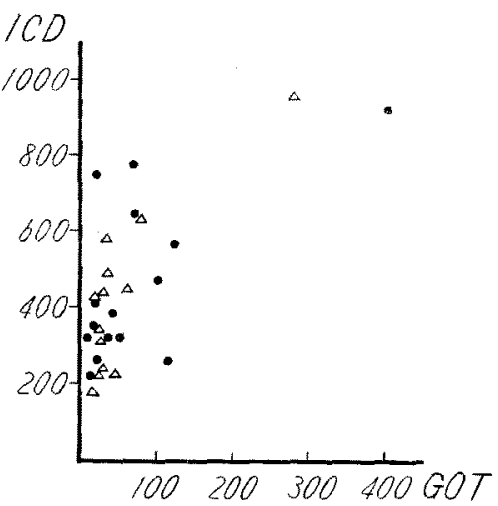

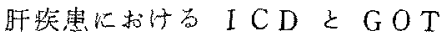




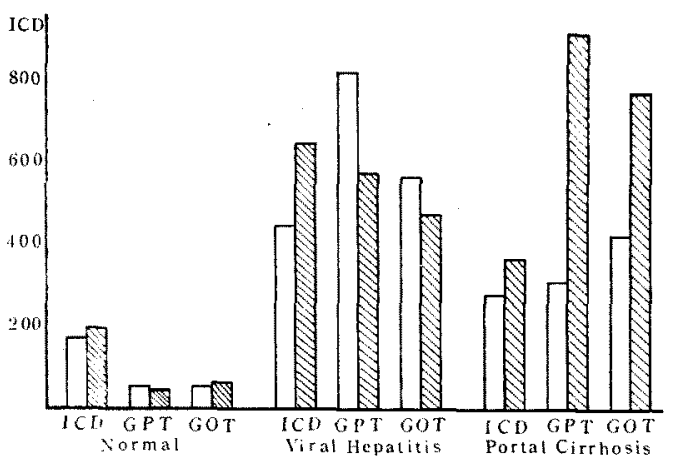

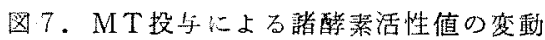

し，投与新および技与後 4 日目の I CD， GP T，GOT各酵素活性值の変動について観察し た。ＩＣD值は正常例，ビールス性旰桨例，䀒硬 変例と兄に投与前それぞれ $174 ， 446 ， 281$ 単位 に対して，㧍与後はおのおの198,641，363単位と 活性谊の上昇を示すが，その上昇率は正常例では 14\%, 䀒硬変例では29\%であるのに対し，特に急 性旰炎例では48\%と著明な上昇を認めた，GP T，GOT值はビールス性肝资ではそれでれ投与 前81，56単位に対し，投与後はおのおの57，47単 位と，ともに下降，䀒硬变では投与前はおのおの 31，42単位に対し，投与後は各90,76単位と, とも に著明な上界走した。なお投与量と酵素活性值 の上昇との間には正の相関は認められなかつた。

(2) 4Cl-testosterone acetate (TA) 投与 例(四 8 )

T A 10mg万至60mg 正常例，旰疾患例に投与し 投与前放上び投与後 4 日目のI CD，GPT，G

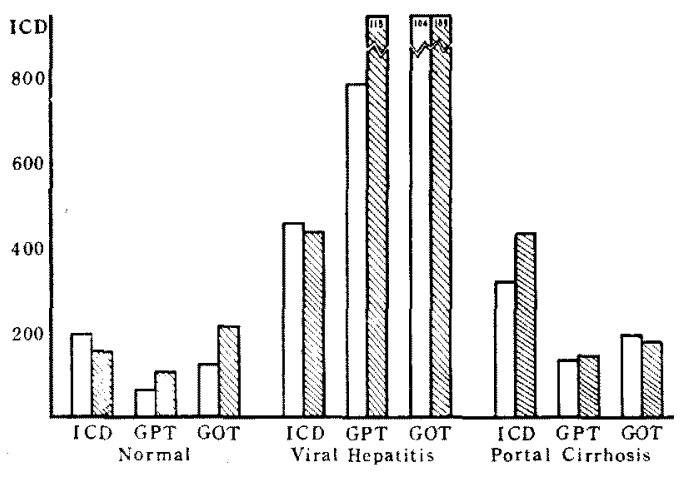

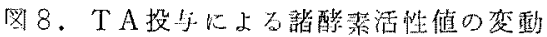

O T各醉䋕活性值の変動を観繁した。I CD值は 盯硬変例を除き，正常例，ビールス性䀒炎例共に 投与前は，それぞれ 198，463単位，投与後 4 日 目ではお㧍の㧍の 160,442 単位と，活性値の下 降, 䀒硬変例はで投与前は 386単位, 投与後は 4 37単位と, 活性值の上昇を示した，GPT，GO Tは，正常例，ビールス性旰炎例に斿いて投与後 活性值上界を示した．MT投与例之同様，投与量 と酵素活性値の上昇との間には正の相関は譛めら れなかつた。

小括. MT投与後4日目にはＩＣD活性値の 增加が認められたが，この傾问は特に䀒障害者に おいて約15\%の增加を示しており，トランスアミ ナーゼにおいては，肝资において沿性值の減少が みられたのに反して，䀒硬変ではその増加加認め られた。これに対しTA投与においては，I CD は正常者および旰资例において減少し，䀒硬変例 ではほぶ不変であつた。

(3) ethylnandrol 投与例 (図9,10)

ethylnandrol 1 日15mg 2 乃至 3 力月間投与 続継中に 2 乃至 3 回にわたり B S P, G P T, GO T值を測定し，それと同晴に他の盰機能検查を行 なつた。症例 1 は“やせ”, 症例 2,4 は胃下垂症， 症例 3 は肝硬変症の患者である，全症例について 一括してみると，いずれも投与開始後約 2 乃至 4 週目頃よりトランスアミナ一ゼ活性值の上昇がみ られるが，更に投与をつぶけるとトランスアミナ 一ゼ值は渐次下降するが，つぎにB S P停洮の起

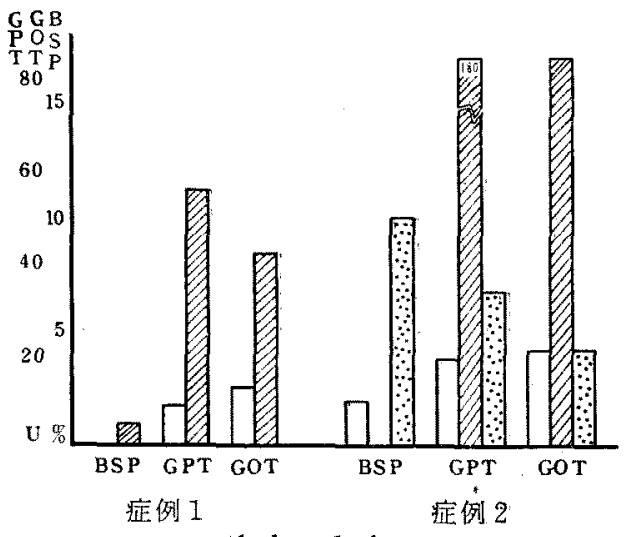

図 9. ethylnandrol 投与例 


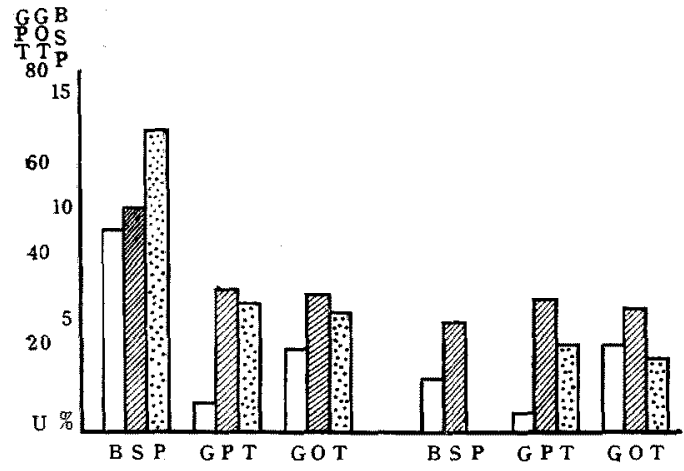

症例 3 症例 4

図10、ethylnandrol 投与例

こるのが観察された。すなわちＢＳＰ停滯の時期 には寸でにトランスアミナーゼ活性値は下降しつ つあるのが観察された．全症例を通じて症例 2 に おいて黄疾指数15を示しな以外には黄疸の発現な く，また症例 3 を除き一般旰機能検查にてを特に 異常值を示したものはなかつた。

(4) 2-hydroxy-methylene-17 $\alpha$-methyldihydrotestosterone (HMD) 投与例 (図11)

71才，女. 本症例は関節りウマチにて入院中， HMD投与により惹起せられたと考えられる黄 疸の 1 例で,プレドニソロンを長期にわたり使用 し, 霄粗鬆症防止の目的でHMDを約 7 加半計 1,695 mg を投与した症例である. 投与前 G P T 12 単位，GOT16単位であつたが投与開始後6力 月目頃よりGPT63単位，GOT56单位とトラン

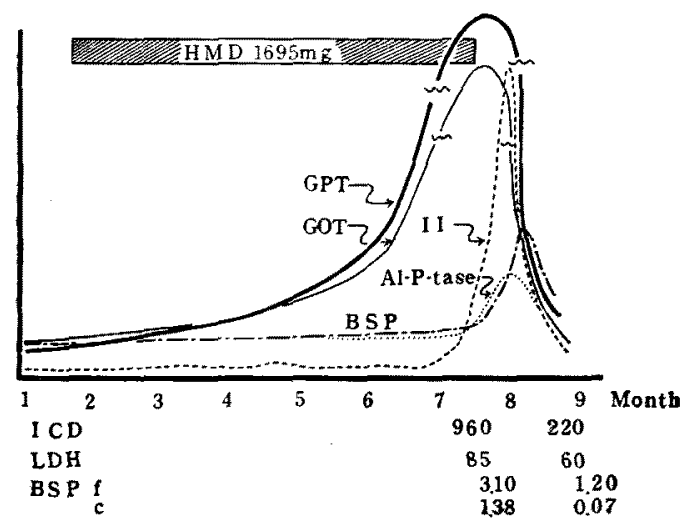

图11. H M D 投年例
スアミナーゼ活性值の上昇が漸次みられ黄疸が発 現したのでHMD投与を中止したものである。黄 疸発現封, 黄渲指数 34, I C D值 960単位, GP T 值 530単位, GOT值 280単位と各醉素活性値は いずれも著しい高值を認めたが，この时期には

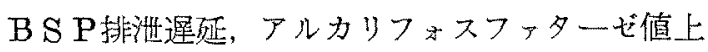
暴などの胆管閉塞所見は認められずHMD投与中 此後, 次第に I CD・GPT・GOT等の醥素活 性值の下降が丸られた時期にも，な扔B S P 停 滞が認められ，アルカリフォスファターゼ值 3.0 と上昇, 黄疸指数 133 と高度黄疸が認められた。

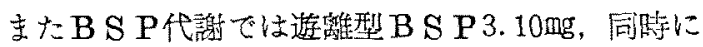
結合型 B S P 1.38mg とともに著しい增加がみ.ら た。投与中止後，的 1 力肘て I CD 220単位, GPT15算位, GOT21単位と減少し, 真㾇指数 11 と正常に復し，また遊離型B S P は1.20mg, 結 合型B S Pは0.07mgをなな。

小括. ethylnandrol 光よび HMD継続投与例 に扔いては一過性にトランスアミナーゼ活性值の 增加が認められ，ついでB S Pの停滞が起こるこ

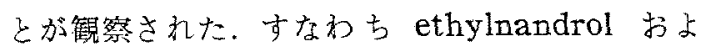
びHMDの投与によつてもMTの如く，一過性の I C D な゙血清醉素活性值の增加がみられるもの と考えられた。

B. 勤物実験成績

（1）健常大9匹をつぎの3群に分けた。すな

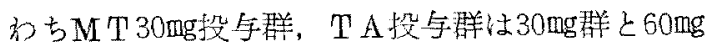
群とし，いずれも非経口的にそ机忝れMT，TA 投一し，投与前（C)当よで投与後 3 日間にわたり 血清 I C D活性值の変勳について観祭した，各投 与群の 4 日間にわたるI CD活性值の平坮在医示 したものが図12である、MT投与群では投与前 381 単位 (C), 投与後第 1 日 363 単位 (1), 第 2 日 354 単位（2)，第 3 日 227单伎（3）上経日的に潮 次活性值減少がみられるが，一方 TA投与群では 30mg群，60mg群いずれも投与得第1日目におのお の458単位，446単位上活性值の上昇が認的ら た.

（2）家震を3群に分けた。すなわち対瀷群 


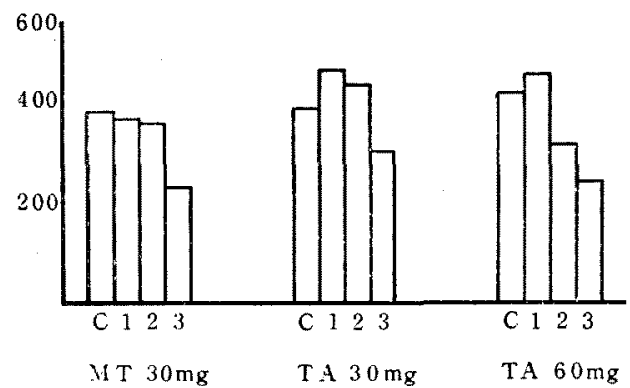

図12. MT投歺及びTA投与によるI C D 值の变動

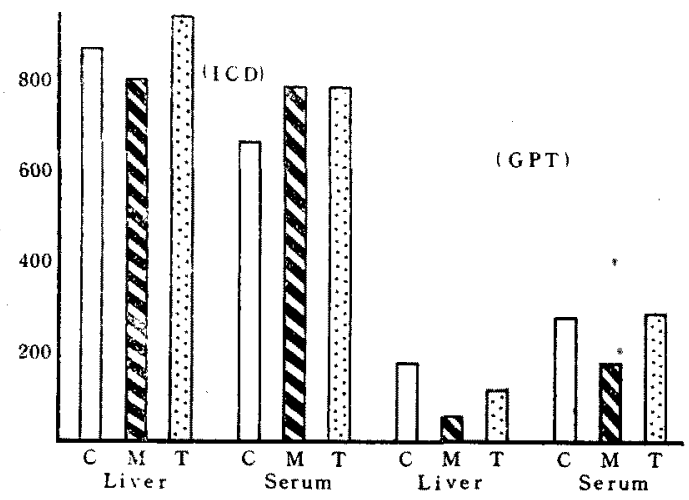

圆13.M.T投与及ひT A 投占による肝内及 び篮清 I C D 仵, G P T 值の変動

(C), M T 30mg投与群 (M)，T A 30mg投与群( T) とし，各群 3 匹宛計 9 匹につき非督口的にMT， TAを投与し24時間後に䀒組䋨及び血液を埰取 し，ICDおよびトランスアミナーゼに関しおの おのの旰内酵素と血清酵素の態度追求した（因 13).

\section{肝内酵素活性測定法}

家鬼䀒組織片は採取後直ちに $\mathrm{KCl}$ 液に浸し，水 泠， $0.25 \mathrm{M}$ サッカーズ溶液を加え，ガラス製 ホモシェナイサーで氷泠しつかホモシェナイズ し，而に0.25Mサッカローズ溶液を100倍になる ように加えた。活性值测定は䀒組織片採取後 2 時 間以内に行なつたＩＣD注清ＩＣD測定方法 によりまたGPT，GOTは100倍ホモシェれー トを更に稀釋して 1,000 倍とし，以下はS-GPT, S-GOTと同しく Sigma-Frankel 法により旰内 活性犆を測定した。ホモシェネート中の各酵素活
性值は䀒 100mg当りの值に換算して示した。

I C D洁性值に関してはMT投与群（M）では 效群(C)の䀒活性は 873に站し，䀒活性は 804 と減少し，血清活性值は刘蹧群 667単位に㸚し 790単位と上昇を示した。一方T A投与群（T） で注効䐋群 (C) の肝活性は 873に対し 941，ま た血清活性值は対炤群 667篻位に対し790篻位々 旰ちよび血清活性值はともに上昇を示した。GP T活性值に関してはMT投与群では対胞群の䀒活 性は18に対し6，血清活性値28単位に対し18単位 と旰，血清ともに減少がみられ，TA投与群では 対郹群の旰活性18に対し12 と減少し，血清活性值 28单位に刘し29算位とや〉上算を示した。

\section{考案}

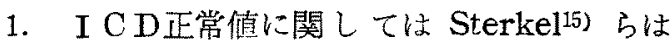

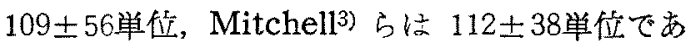
つたと報告し、これらはいすれれ Williams-Ashman 法によるものである. Bowers4) は90土 34.3算保，また本邦では高杉5が Bowers 法に より $5.7 \pm 2.1$ 単位であつたと報告している。跖 者は Taylor 9)の方法に準じて測定を行ない，正 常男子20例の平均は $197 \pm 35.2$ 単位，正常女子16 例の平均は $187 \pm 29.3$ 単位，正常男女36例の平均

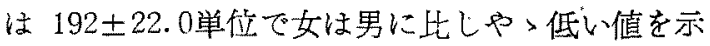
した.

2. 急性肝炎患者において血清 I CD值が高活 性を示すことはすでに諸家の研究により知られて おり，Sterkel15)によれば最高は正常值の15倍に 避するという報皆もある。著者の急性䀒炎15例の 平均は 464単位で，最低 220単位より最高 920 単 位に分布し, 最高活性值は正常值の4倍強であ 万.しかし黄㾝前期 3 例の I C D の平均が 772 単 位であり，黄疸期 5 例の平均が506算位を示した ことは，黄疸期以前に I CD活性值の上昇がある ことを示しており，われわれの黄疸前期例の平均 が諸家の報告より低いことは杢院の如き病院の性 桥加らして旰资早期の例を観察する機会が少なか つたことによると考えられる。すなわち他の䀒機 能検查，T T T, C C F，血清ビリルビン量增加 
以前に I C Dは最高活性を示し，急性肝炎におけ る本酵素の高活性は初期の 7 日間であるという報 告3)と一致している. 臨床経過良好のものでは第 2週目頃より I C D 倠は下降し, 諸䀒機能検查の 改善に先行して下降するちのと考えられる。なお 本酵素己他の䀒機能検查成績とを比較検討すると 黄病指数あるいは他の翏質反応とは有意な関係は みられず，トランスアミナーゼ活性值，特に GP Tと泟の相関々係が翏められた。

3. 慢性旰资症例においてはその半数に相当す る4例の I CD值はほぐ正常值を示しているが, 全 8 例のI CD值の平均は 409単位で正常值のほ 玨2倍である。しかし個々の症例を検討すると症 矵6，80如く急性䀒炎初期にるられるような活性 值上景示主症例もみられるが，他の症例の如く ほとんど正常值を示すものもあり，本酵素の活性 值上景は慢性畈炎経過中に起こる病巣の再然によ るものと考えられる16)17)。この際にお訬る G P T 活性值にも上景を示す症例としからざる症例とが あるか゚，GPT上昇を示す症例では常にＩＣD活 性上昇を譛めるのに反し，I C D活性值上昇例に

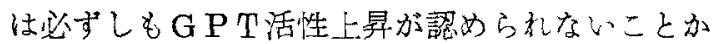
ら，I C D活性值上昇の機序はGPTより旰疾患 の再然に対し，より特異的であるか，あるいは時 期的に I CDがG P T上り早く活性值上昇を示す 傾向があるものと推察される。

4. 䀒硬変症では管睡例を除いた I C D 值の平 均は386単位で軽度上昇を示し GPT, GOTは 正常範囲内にある。それらのうち腹水, 脾腫, 腹壁 静脈怒張，食道静脈瘤を伴なう症例のＩＣＤ值は ほ ぶ正常範囲内にあり，武内18) らが血清トランス アミナーゼについて観察した如く，I C Dにつ いても代償不全にある症例が代筫期にある症例よ りも高値を示すとはいえないと考えられる，昏睡 例においてはＩＣD活性は中等度上暑を示してお り，昏睡の招来する時期よりはや>遅れて上昇す る傾向にある。このように䀒硬变症にお打る I C D活性値は正常値をや〉上わるが，急性肝炎の 如く著明な上昇を示さない，すな⿰力口䀒硬変にお
いては䀒の線維化に伴なう䀒細胞数の絶刘的減少 により：トトコンドリア中に存在すると老えられ る本酵素も絶対数が減少し，非活勤性の時期には 血清中ＩＣＤ值は流ぶ正常值を示すが，ひと度活 動性の悠瘤，あるいは壊死機転の発生が起こると 線維化せる旰の残存旰实質に破綻を生じ，血流中 八の本酵素の放出が行なわれ血清 I C D值活性上 䒜が起こると老えられる。したがつて慢性䀒炎, るいは䀒硬变症においてＩＣD活性を測定するこ とにより，䀒の炎症乃至壤死機転の消長を察知す ることが可能であり，ひいてはそれら疾舁の予後 をも予測することにも役立つものと考えられる。

5. 各種閉塞性黄㾞抢よび胆石症など胆管乃至 は胆道疾㭧における血清 I C D 活性値は正常より 高值を示すものまで種々認められる。しかしこれ らの症例を他の䀒機能検查より類推して, 䀒実筫 あるいは䀒細胞に障害のおよんでいるものと，そ うでないものとに区劼して観察すると，閉塞性黄 疾のうち 1 例と胆石症 3 例に括いて認められる如 くICD值怔常であり，他の例は正常值を上ま 方る成績加得られた。 Sterkel15) は䀒外性開塞性 黄㾝の症例においてはI C D活性値の上昇を諗

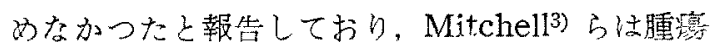
の王迫による肝外性黄疸 4 例中 3 例に軽度のI C D活性倌上昇を認めたと報告している。これら

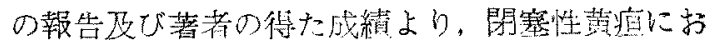
ける血清 I C D値の上昇は篹なる胆管閒塞のみて

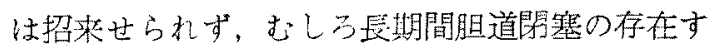
ることにより二次的に旰細肘障害が招头さられ

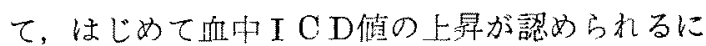
至るものと思考女られた。このこ上は外科的黄疸 の手街嗰坎に際してどの程度に实質障害を来たし ているかを知る際に有网であるうと考えられる。

6. 急性䀒炎, 慢性肝炎, 所硬变を通じて血清 I C D值の変動の面上り観察すると血清 I C D值 は黄㾝前期に招いて非常に高い值を示すが，黄㾝 の消退に先だつて I C D值の下降がみられ，慢性 䀒炎に㧈いて注正常值と異常值の閒を変勤しなが 
ら経過するが，盯硬変に至ると正常值を多少上ま わりながら変動し，旰昏嗹においては皆睡の発生 より多少扔くれて活性值上昇が認められる。すな わち急性䀒炎に扮いては盰実質に広範な炎症性機 転がおよび，IＣD活性值の著しい上昇が認めら れるが，炎症の軽快に伴なつてI CD活性值は 正常值に復する。しかしこれらの経過が遷延化し て慢性旰炎の状態に至ると，その経過中炎症乃至 は壞死機転が部分的にくり返して招来せられる結 果，その時期においては中等度のＩＣＤ活性值上 昇が認められるが，更に䀒硬変期にいたるもこの 傾向が継続せられ，䀒昏睡の発現により再び䀒に 壞死万至炎症機転が惹起女られＩＣD值の上昇が 起こるものと考えられる。すなわち旰障害時にお ける血清 I CD値の上昇はいずれの場合において も、䀒の線維化の如き機転においては增加するこ となく，壞死乃至は资症の再然の如き時期におい て上暴が認められるものと考えられる。したがつ て I CD活性值をしばしば測定することにより， 完全な䀒障害の治瘾をうらら゙けることができる

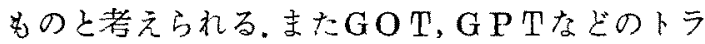
ンスアミナーゼ值においてもこの傾向は認められ るが，I C D值はこれら醉菜よりも敏感に，また特 異的にその状態を示するのと考えられる.Wróblewski ${ }^{19)}$ がトランスアミナーゼ活性値さ中心に 他の盰機能検查と比較して䀒硬変を分類し 4 群に わけているが，これらの分類はＩＣD活性の画か らも首肯せられるところであり，栖言するなら ば，I C D活性值上昇を示寸場合は䀒における活 動性の幾転が進行中であることを示すをのとも老 えられる。

7. エリテマトーデス 2 例, ワイル氏病 2 例, 腫 演 2 例，贯溃瘍 2 例，ネフローゼ 2 例，すべて I C D活性值は正常を示しており，糖尿病 7 例中 1 例に中等度活性上昇をみるが他の䀒機能成續は正 常であり，心筋障害 4 例においてはうち 1 例のみ にI CD值の上昇を諗めたが，死後剖検にて著明 な“うつ血肝，を証明した：Stanotord は心筋 硬塞でも一過性に I C D活性上昇をみとめたと報
告し，またBowers らは心能硬塞や肺栓塞に $\mathrm{G}$ OT，GPT，あるいはI C Dなどの諸酵素の活 性値上舁を示す場合のあることを報告している が，その原因は主として心能硬塞のようなショッ クにより䀒八の酸絜供給が不去分となり，急性の 䀒葉中心細胞が壞死を起こすためであると逝へて いる。すなわちこれらの症例のうちＩＣD值上昇 の認められたものは、䀒を中心とした細胞障害に 由来するものと推檫せられる。しかし心筋硬塞に ついては例数も少ないのでなお今後の検討を要す るものと考えられる。

8. methyltestosterone 㧍よびその誘導体を 投与した際に黄疸がみられることはすでにWerner ${ }^{11)}$ らにより報告されているところであり，ま たその剖検例，あるいは臨床例についてもWerner ${ }^{11)}$, 冲中 ${ }^{20)}, K_{\text {ory }}^{7)}$, Schaffner ${ }^{8)} ら に よ り$ 報 告されている。一方これらの誘導体を投与した際 に螌トランスアミナーゼ活性值, LDH，アル ドラーゼなどの增加することが認められている が，その活性值增加の原图については未だ充分に 解明されていない，著者は methyltestosterone およびその誘導体を一回投与し，その際における 血清酵淙活性值の变動, 特にこれら物質の I C D 活性值に抢よほす影響について䂓察した。上述の 如くMTを一回投手した際にみられる I C D值の 変動梳性䀒炎例において最も著しく，ついで畈 硬变例，正常例の䐓に墳加することが観察せら れたが，これらの関係は他の酵素には認わられ ず、トランスアミナーゼ活性值においては䀒炎例 に预いて一時減少する傾问が譛められた。TAの 一回投与に敃いてはＩＣＤ，トランスアミナーゼ 活性值共に一定した傾向は認められなかつた。こ れらの関係を更に詳細に観察するため健常犬にM T方よびTAを一回投与して経日的に酵素活性值 を観察すると，MTにおいては投与後 4 日間の観 察では I C D值が㴬次減少するのに反し，TA投 与群において性第 1 日目のみにI C D活性値が堌 加することが認められる。すなわち臨床例と実験 例を対比して考察すると，MT，TAともに酵菜 
活性値特にICD活性值さ埍加せしめる作用があ るが、MTはその作用がながく、T A は一過性のも のであることが理解せられると共に，その管加は 䀒炎の如き炎症性病変を呈する場合に著しいこと が篗察せられた。更にこの事実は篆雭においてM TあるいはTAを別マに投与して血中および旰組 織中のＩＤ＼cjkstart活性值を観察すると，MTおよずT A投与群其に投与24時間後に血清中 I C D值は增 加するのに対し，䀒中のＩＣＤ值はMTに扔いて は減少，TAにおいては堌加が琶められることか ら，MTおよびTAの盰に対する作朋が多少異な り，したがつて臨床例にみられた如き結果の相違 を来たしたものと者えられた。これらの成績より MTおよびTAは一回の投与によつて血中酔素 特にI C D値の增加を来たす作用があるものと考 えられるが，MTの作用は急速でありTAの作用 は緩徐であるものと考えられた。一方HMDおよ び ethylnandrol 投与による臨床例を仔細に観 察すると，まず血清酵素值の增加が認められ，つ ぎにBSPの停渺, 更には萯疸指数,アルカリフォ スファターゼの増加汃観察せられる。すなわ男 性ホルモンおよびその誘導体投与により，まず認 められる变化注近中諸䤏素の增加であり，つぎに

B S P停㴆であることが理解される.

男性ホルモン誘導体投与による酵素活性值の上 昇が如何なる機序によるかは，われわれの実験に おいては完全には二れを明らかにすることはでき なかつたが，BＳＰの停溓洔期においても血清蛋 白濃度あるいは血清翏筫反応などに異常は認めら

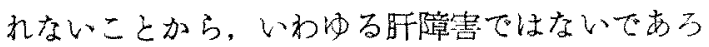
うかとも考えられるが, Kory7) らの報告による

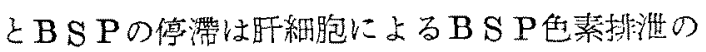
崌㱏に由来するものであるとし，また著者の例に みられた如く残留ＢＳＰの組成が絬合型のものが 多かつたことよりすれば，明らかに盰細胞よりの B S P排泄が障畫せられているものと考えざるを 得ない，寸なわち投与初期にみられる血中酵素上 昇は䀒細胞中における物質移送に障害があること
を示しており，その結果としてBＳP停滯という 現象に到達守るものと考えられる。この現象注䀒 に㧍ける物質移送に特に重瑟であると考えられて いるミトコンドリアに著しいものと教えられ，し たがつて MT，TA投与による䓔素活性值の変動 が特にI CDに顕著である所以であるう。

\section{結論}

以上の如き臨本的ならでに实験的検查の結果, すなわち, 船中 I CD, GOT, GPT, $\mathrm{LDH}$ などの測定結果から, 以下の如き結諞に到達し た.

1) 正常男子20例の I CD值の平均は $197 \pm$ 35. 2単位, 正常女子16例の I C D値の平均は 187 土29.3単位; 正常者男・女計36例の路均は $192 \pm$ 22.0単位であつた (Taylor 法).

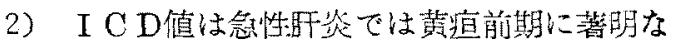
活性值上㫧，また旰性皆睡時において中等度活性 值上昇を諗めた。慢性旰资, 䀒硬变ではI CD值 は正常乃至は正常值を多上まわる活性值を示し たＩＣD活性値上昇とトランスアミナーゼ活性 值とは正の相関を認めたが，他の朋機能㭘查とは 青意の相関を認めなかつた。

3）閉塞性黄㾝におけるIＣＤ活性值上昇は， 単なる胆管閉塞のみで招来されるとは考えられ ずむしろ胆道閐塞に上るこ次的な旰細盷障害に 際して活性值上昇を示す孝のと考えられた。

4) 慢性乫恣，矿硬变なぼの慢性肝障害におけ

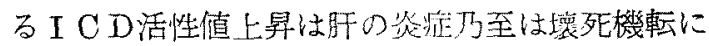
由来するものと考えられ，したがつて慢性肝炎， 旰硬変に際してIＣD活性值を測定することによ り䀒の炎症至は壤死機転の消骎を推測する一助 となり，更に慢性䀒疾患の予後の判定に役公つる のと老えられた。

5）エリテマイーテ゚ス 2 例、ワイル氏病 2 例, 腫瘍 2 例，胃潰寡 2 例，ネフローゼ 2 例ではすべ て I C D活性傎は正常，心筋障㕩４例中 1 例，粕 疗病 7 例中 1 例にのみ I C D活性值上暑を認めた に過ぎなつた。したがつてＩＣD活性值上眾は 即疾患に特異的であると考えられた。 
6)男性ホルモン㧍よびその脬導体である蛋白 同化ホルモン投与により，まずＩＣD，トランス アミナーゼなどの血清酵素值の増加が認められ， つぎにBSPの停滯，更には黄应指数，アルカ リフォスファターゼの增加が諗められた。投与初 期にみられた血清酹素值の増加は旰細胞中におけ る物罂移送機転に障管があるものと考えられ，そ の結果こしてBＳP停㠿が起こると思考された。

\section{文献}

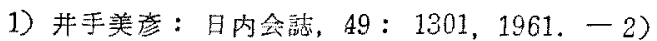
Wolfson, S.K. and Williams-Ashman, H.G.: Proc. Soc. Exper. Biol. \& Med., 96: 231, 1957. 3) Mitchell A.: Gastro-enterology, 39: 305, 1960. -4) Bowers, G.N.: Clini. Chemi., 5 :

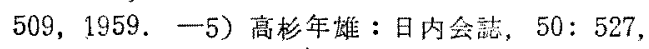

1961. -6) 石并策央：最新医学, $16: 45,1961$. -7) Kory R.C.: Am. J. Med., $26: 243,1959$. -8) Schaffner: 'Am. J. Med., 26: 249, 1959. -9) Taylor, T.H. and Michael E. Friedman: Clini. Chemi. 6: 208, 1960. - 10) Hill, B.R.: Cancer Research, 16 : 460, 1956. - 11) Werner, S.C.: Am. J. Med., 8: 325, 1550. -12) Al. maden, P.J.: Ann. Int. Med. $40: 146,1952$. -

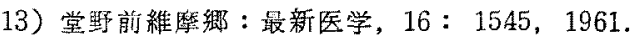
-14) 滕木司馬之助: 最新医学, $16: 1614,1961$. -15) Sterkel, R.L.: J. Lab. \& Clin. Med., 52 : 176, 1958. -16) Chinsky M.: J. Lab. \& Clini. Med., 47 : 108, 1956. -17) Madsen S.: Brit. M.J. I；543，1958. -18) 武内重五郎: 日消誋, 59 : 411, 1962. - 19) Wróblewski F.: Advances in clinical Chemistry, $1 ; 313,1958$. -20)冲 中重婎：最新医学，17；1187，1962. 